\title{
Winter-Spring fauna of Cladocera of Dali Bai Autonomous Prefecture, Yunnan Province, China
}

\author{
Artem Y. Sinev ${ }^{1,2, *}$, Yangliang $\mathrm{Gu}^{3}$ and Bo-Ping $\mathrm{Han}^{3}$ \\ ${ }^{1}$ Biological Faculty, M.V. Lomonosov Moscow State University, Leninskie gory, Moscow 119991, Russia. \\ 2 A. N. Severtsov Institute of Ecology and Evolution, Leninsky Prospect 33, Moscow 119071, Russia. \\ ${ }^{3}$ Department of Ecology and Institute of Hydrobiology, Jinan University, Guangzhou 510632, China.. \\ * Corresponding author: artem.sinev@gmail.com
}

Received: 02/04/19 Accepted: 12/09/19

\begin{abstract}
Winter-Spring fauna of Cladocera of Dali Bai Autonomous Prefecture, Yunnan Province, China

The Cladoceran fauna of Dali Bai Autonomous Prefecture, Yunnan Province, China was investigated in January 2015 and April 2016. Water bodies studied include Lake Erhai, second largest lake in Yunnan, several large lakes and reservoirs, and numerous smaller water bodies, located at 1800-2000 m above sea level. The winter-spring fauna of the area included 34 species, most of them Palearctic or widely distributed species, with plus five predominantly Paleotropical taxa. Thirty-one species occurred in Lake Erhai, while species richness in other water bodies not exceeded 14 species. Only parthenogenetic females were found in the majority of species, suggesting that Dali area climate is mild enough to allow Palearctic species to overwinter as active populations. Ilyocryptus cuneatus Śtifter, 1988 is recorded for China for the first time; Alona kotovi Sinev, 2012, Camptocercus uncinatus Smirnov, 1971 and Disparalona ikarus Sinev \& Kotov, 2011, are also first records for continental China.
\end{abstract}

Key words: Cladocera, zoogeography, morphology, China, Yunnan

\section{RESUMEN}

Fauna invernal y primaveral de cladóceros de la prefectura autónoma de Dali Bai, provincial de Yunnan, China

Durante enero de 2015 y abril de 2016 se investigó la fauna de cladóceros de la prefectura autónoma de Dali Bai, provincia de Yunnan, China. Las masas de agua estudiadas incluyeron el lago Erhai, segundo en tamaño de Yunnan, varios lagos grandes y embalses, y numerosos pequeños cuerpos de agua, situados a una altitud de 1800 - 2000 msnm. La fauna invernal y primaveral de cladóceros incluye 34 especies, muchas de ellas de distribución Paleartica o ubiquistas, con sólo cinco taxones encontrados de predominancia Paleotropical. Se encontraron 31 especies en el lago Erhai, mientras que la riqueza en otras masas de agua no superó las 14 especies, mostrando la mayor diversidad de biotopos en este lago. Sólo se encontraron hembras partenogenéticas de la mayoría de las especies, lo que sugiere que la zona de Dali tiene un clima suficientemente suave como para permitir a las especies paleárticas pasar el invierno como poblaciónes activas. Ilyocryptus cuneatus Śtifter, 1988 se ha citado en China por primera vez; Alona kotovi Sinev, 2012, Camptocercus uncinatus Smirnov, 1971 y Disparalona ikarus Sinev \& Kotov, 2011, se han citado también por primera vez para la China continental.

Palabras clave: cladóceros, zoogeografía, morfología, China, Yunnan. 


\section{INTRODUCTION}

The Cladocera of East Asia have been actively investigated during the last decades. Local faunas were recently studied in Far East of Russia (Kotov et al., 2011ab), South Korea (Kotov et al., 2012, 2017; Jeong et al., 2014) and China (Sinev et al., 2015; Chertoprud et al., 2017) and numerous new taxa were described from the region (Kotov et al., 2006; Korovchinsky, 2009; Kotov \& Sinev 2011; Jeong et al., 2012, 2013, 2017; Sinev et al., 2016) Checklists were published for Korea (Jeong et al., 2014) and China (Xiang et al., 2015; Ji et al., 2015). But most regions of continental China are not yet well studied, with most faunistic data for the country based on ecological work with doubtful identifications (Xiang et al., 2015; Ji et al., 2015).

The main water body of Dali Bai Autonomous Prefecture (Yunnan Province, China) is Lake Erhai, the second largest lake in Yunnan Province. It is a fault lake situated at $1972 \mathrm{~m}$ above sea level. Its area is about 250 square kilometers; length of the lake is about 40 kilometers and width is about 7-8 kilometers; average depth is $11 \mathrm{~m}$. Several large natural lakes - Xihu, Zibi, Jainhu, Chenghai and Shuizhangdi, as well as numerous smaller reservoirs and artificial ponds are located in the vicinity of Lake Erhai at altitudes of 1800-2000 m. Lake Erhai region is rather insular, surrounded by mountainous ranges with no lentic water bodies. Distance from Lake Erhai to Lake Dianchi (Kunming Area), the largest lake in the region, is over $250 \mathrm{~km}$, with no natural lakes in between, but several small reservoirs were constructed there in the course of the $20^{\text {th }}$ century.

The Cladoceran fauna of the area has been poorly studied; most data come from previous hydrobiological studies of Lake Erhai (Lu, 1939). They revealed 12 species of Cladocera there. Pelagic communities of Lake Erhai were investigated on a regular basis (Li et al., 1963; Wu \& Wang, 1999; Yang et al., 2014), and Cladocera remains in the lake sediments were also studied recently (Liu et al., 2014; Lu et al., 2016). During the last century, Lake Erhai became subject to eutrophication, exotic fish introduction and degradation of natural macrophyte communities, lead to strong changes in cladoceran species composition (Liu et al., 2014; Lu et al., 2016). No data for other large water bodies in Dali area are available. While records for Yunnan cladocerans in general are numerous (see Xiang et al., 2015; Ji et al., 2015), only few records refer specifically to Dali Area.

The aim of present study was to evaluate spring-winter fauna of Cladocera of Lake Erhai and other water bodies of Dali area (Table 1), with special attention to the littoral fauna.

\section{MATERIALS AND METHODS}

Samples were collected by the two first authors in January 2015 and in April 2016 by a standard plankton net ( $25 \mathrm{~cm}$ diameter, $100 \mu \mathrm{m}$ mesh size) and dip net (100 $\mu \mathrm{m}$ mesh size) and immediately fixed in $3 \%$ formaldehyde. In locations with a complex structure of the littoral zone, samples were taken in different zones of vegetation, i.e. plants with submerged or floating leaves were rinsed by water to a bucket, reed-like plants scraped by dip nets, etc. Specimens were selected from the samples under a binocular stereoscopic microscope Biolam MBI-10, placed on slides in a drop of a glycerol-water mixture and studied under microscopes Olympus CX-41 and CX-51. Dissections were conducted by electrolytically sharpened tungsten needles. Measurements were conducted using an eyepiece-micrometer. Drawings were made by means of camera lucida.

\section{RESULTS}

We recovered 34 species of Cladocera, including a single species of Sididae, 11 species of Daphnidae, a single species of Macrothricidae, two species of Ilyocryptidae, a single species of Bosminidae, and 18 species of Chydoridae (see Table 2). Ilyocryptus cuneatus Śtifter, 1988 is here recorded for China for the first time. Three more species, Alona kotovi Sinev, 2012, Camptocercus uncinatus Smirnov, 1971 and Disparalona ikarus Sinev \& Kotov, 2011, known only from Hainan Island (Sinev et al., 2015) are recorded for continental China for the first time. Comments on the taxa are represented below. Among 34 species recorded, 7 are planktonic and 27 are 
Table 1. List of sampling sites ( $\mathrm{W}$ - winter samples, $\mathrm{S}$ - spring samples). Lista de lugares de muestreo (W-en invierno, $S$ - en primavera).

\begin{tabular}{|c|c|c|c|c|}
\hline & Sampling site & Latitude & longitude & Date \\
\hline W1 & $\begin{array}{l}\text { Lake Erhai, Xi'er river mouth within Dali city, stone } \\
\text { embankment, abundant submerged macrophytes and filamentous } \\
\text { algae }\end{array}$ & N 25⒊ $36^{\prime} 11.4^{\prime \prime}$ & E $100^{\circ} 13^{\prime} 43.9^{\prime \prime}$ & $19-01-2015$ \\
\hline W2 & $\begin{array}{l}\text { Lake Erhai, stone embarkment within Dali city, abundant } \\
\text { submerged macrophytes and filamentous algae }\end{array}$ & N $25^{\circ} 36^{\prime} 26.7^{\prime \prime}$ & E $100^{\circ} 14^{\prime} 27.8^{\prime \prime}$ & $19-01-2015$ \\
\hline W3 & $\begin{array}{l}\text { Decorative pond within Dali city, with rock bottom without } \\
\text { macrophytes }\end{array}$ & N $25^{\circ} 36^{\prime} 33.9^{\prime \prime}$ & E $100^{\circ} 15^{\prime} 08.8^{\prime \prime}$ & $19-01-2015$ \\
\hline W4 & Lake Erhai, low clay shore, submerged terrestrial grasses & $\mathrm{N} 25^{\circ} 39^{\prime} 53.2^{\prime \prime}$ & $\mathrm{E} 100^{\circ} 17^{\prime} 01.9^{\prime \prime}$ & 19-01-2015 \\
\hline W5 & Lake Erhai, open rocky littoral, filamentous algae on stones & N $25^{\circ} 39^{\prime} 52.9^{\prime \prime}$ & E $100^{\circ} 16^{\prime} 52.6^{\prime \prime}$ & 19-01-2015 \\
\hline W6 & $\begin{array}{l}\text { Lake Erhai, littoral zone with water hyacinth (Eichhornia } \\
\text { crassipes) }\end{array}$ & N $25^{\circ} 41^{\prime} 27.2^{\prime \prime}$ & $\begin{array}{l}\text { E } 100^{\circ} 16^{\prime} \\
26.6^{\prime \prime}\end{array}$ & 19-01-2015 \\
\hline W7 & Lake Erhai, open rocky littoral, filamentous algae on stones, & $\mathrm{N} 25^{\circ} 44^{\prime} 00.7^{\prime \prime}$ & E $100^{\circ} 13^{\prime} 56.3^{\prime \prime}$ & 19-01-2015 \\
\hline W8 & $\begin{array}{l}\text { Lake Erhai, rocky littoral with water caltrop (Trapa sp.) and } \\
\text { filamentous algae on rocks }\end{array}$ & N $25^{\circ} 49^{\prime} 53.2^{\prime \prime}$ & E $100^{\circ} 13^{\prime} 09.9^{\prime \prime}$ & $19-01-2015$ \\
\hline W9 & Lake Erhai, low clay shore, submerged terrestrial grasses & $\mathrm{N} 25^{\circ} 51^{\prime} 11.9^{\prime \prime}$ & E $100^{\circ} 13^{\prime} 14.9^{\prime \prime}$ & 19-01-2015 \\
\hline W10 & $\begin{array}{l}\text { Lake Erhai, rocky littoral with water caltrop (Trapa sp.), water } \\
\text { hyacinth (Eichhornia crassipes), and filamentous algae on rocks }\end{array}$ & N $25^{\circ} 53^{\prime} 43.1^{\prime \prime}$ & E $100^{\circ} 12^{\prime} 52.0^{\prime \prime}$ & $19-01-2015$ \\
\hline W11 & $\begin{array}{l}\text { Lake Erhai, low clay shore with water hyacinth (Eichhornia } \\
\text { crassipes) and water fern (Salvinia sp.) }\end{array}$ & N 255 57'09.9" & E $100^{\circ} 09^{\prime} 24.1^{\prime \prime}$ & 19-01-2015 \\
\hline W12 & Paddy field & $\mathrm{N} 25^{\circ} 56^{\prime} 10.5^{\prime \prime}$ & $\mathrm{E} 100^{\circ} 06^{\prime} 30.8^{\prime \prime}$ & 19-01-2015 \\
\hline W13 & $\begin{array}{l}\text { Temporary pool with submerged terrestrial vegetation and water } \\
\text { fern (Salvinia sp.) on meadow close to W12 }\end{array}$ & & & $19-01-2015$ \\
\hline W14 & Ornamental pond with stone embankment, without macrophytes & $\mathrm{N} 25^{\circ} 51^{\prime} 13.0^{\prime \prime}$ & E $100^{\circ} 13^{\prime} 35.4^{\prime \prime}$ & 19-01-2015 \\
\hline W15 & Irrigation ditch in garlic field & $\mathrm{N} 26^{\circ} 00^{\prime} 41.0^{\prime \prime}$ & E $100^{\circ} 04^{\prime} 25.8^{\prime \prime}$ & 20-01-2015 \\
\hline W16 & $\begin{array}{l}\text { Lake Xihu, littoral zone with water hyacinth (Eichhornia } \\
\text { crassipes) and abundant submerged macrophytes }\end{array}$ & $\mathrm{N} 26^{\circ} 00^{\prime} 56.1^{\prime \prime}$ & E $100^{\circ} 03^{\prime} 07.5^{\prime \prime}$ & 20-01-2015 \\
\hline W17 & Lake Xihu, littoral zone with abundant submerged macrophytes & $\mathrm{N} 26^{\circ} 00^{\prime} 57.5^{\prime \prime}$ & E $100^{\circ} 03^{\prime} 09.7^{\prime \prime}$ & 20-01-2015 \\
\hline W18 & $\begin{array}{l}\text { Pond near Lake Xihu, overgrown with water lily and submerged } \\
\text { macrophytes }\end{array}$ & N $26^{\circ} 00^{\prime} 54.5^{\prime \prime}$ & E $100^{\circ} 03^{\prime} 12.4^{\prime \prime}$ & 20-01-2015 \\
\hline W19 & $\begin{array}{l}\text { Pond near Lake Xihu, overgrown with submerged macrophytes, } \\
\text { close to W18 }\end{array}$ & - & - & 20 \\
\hline W20 & Paddy field & $\mathrm{N} 26^{\circ} 00^{\prime} 57.7^{\prime \prime}$ & E $100^{\circ} 03^{\prime} 13.2^{\prime \prime}$ & 20-01-2015 \\
\hline W21 & Lake Zibi, stone embankment, abundant submerged macrophytes & N $26^{\circ} 08^{\prime} 04.5^{\prime \prime}$ & E $99^{\circ} 57^{\prime} 20.3^{\prime \prime}$ & $20-01-2015$ \\
\hline W22 & Lake Zibi, low coast, submerged terrestrial grasses & N $26^{\circ} 08^{\prime} 04.1^{\prime \prime}$ & $\mathrm{E} 99^{\circ} 57^{\prime} 08.1^{\prime \prime}$ & 20-01-2015 \\
\hline W23 & Fish pond close to Lake Zibi, abundant filamentous algae & N $26^{\circ} 08^{\prime} 05.3^{\prime \prime}$ & E $99^{\circ} 57^{\prime} 07.2^{\prime \prime}$ & 20-01-2015 \\
\hline W24 & Yuhua reservoir, low coast with submerged terrestrial grasses & N $26^{\circ} 25^{\prime} 35.4^{\prime \prime}$ & E $99^{\circ} 57^{\prime} 54.0^{\prime \prime}$ & 20-01-2015 \\
\hline W25 & Lake Jainhu, shallow littoral zone with submerged macrophytes & N $26^{\circ} 29^{\prime} 06.4^{\prime \prime}$ & E $99^{\circ} 56^{\prime} 36.9^{\prime \prime}$ & $20-01-2015$ \\
\hline W26 & Pond in agricultural area, without macrophytes & N $25^{\circ} 43^{\prime} 26.3^{\prime \prime}$ & E $100^{\circ} 10^{\prime} 54.6^{\prime \prime}$ & 21-01-2015 \\
\hline W27 & Fish pond in agricultural area, without macrophytes & N $25^{\circ} 43^{\prime} 42.3^{\prime \prime}$ & E $100^{\circ} 10^{\prime} 59.6^{\prime \prime}$ & 21-01-2015 \\
\hline W28 & $\begin{array}{l}\text { Lake Erhai, submerged terrestrial vegetation and water hyacinth } \\
\text { (Eichhornia crassipes) }\end{array}$ & $\mathrm{N} 25^{\circ} 43^{\prime} 51.8^{\prime \prime}$ & $\mathrm{E} 100^{\circ} 11^{\prime} 14.4^{\prime \prime}$ & $21-01-2015$ \\
\hline W29 & $\begin{array}{l}\text { Lake Erhai, rocky littoral with water hyacinth (Eichhornia } \\
\text { crassipes) and submerged macrophytes }\end{array}$ & N $25^{\circ} 44^{\prime} 00.0^{\prime \prime}$ & E $100^{\circ} 11^{\prime} 04.6^{\prime \prime}$ & 21-01-2015 \\
\hline W30 & $\begin{array}{l}\text { Irrigation channel going from Lake Erhai, about } 50 \mathrm{~m} \text { from the } \\
\text { lake, muddy bottom and submerged macrophytes }\end{array}$ & N $25^{\circ} 44^{\prime} 15.3^{\prime \prime}$ & E $100^{\circ} 10^{\prime} 18.6^{\prime \prime}$ & 21-01-2015 \\
\hline W31 & Reservoir, clay shore with submerged terrestrial grasses & $\mathrm{N} 25^{\circ} 27^{\prime} 16.2^{\prime \prime}$ & $\mathrm{E} 100^{\circ} 11^{\prime} 42.8^{\prime \prime}$ & 21-01-2015 \\
\hline W32 & Chenguanchang reservoir, clay shore without macrophytes & $\mathrm{N} 25^{\circ} 24^{\prime} 19.8^{\prime \prime}$ & E $100^{\circ} 11^{\prime} 18.5^{\prime \prime}$ & 21-01-2015 \\
\hline W33 & Pool in river valley & $\mathrm{N} 25^{\circ} 24^{\prime} 12.2^{\prime \prime}$ & $\mathrm{E} 100^{\circ} 12^{\prime} 05.6^{\prime \prime}$ & 21-01-2015 \\
\hline S1 & $\begin{array}{l}\text { Pond near Lake Xihu, overgrown with water lily and submerged } \\
\text { macrophytes (same loc. as W18) }\end{array}$ & $\mathrm{N} 26^{\circ} 00^{\prime} 54.5^{\prime \prime}$ & E $100^{\circ} 03^{\prime} 12.4^{\prime \prime}$ & $19-04-2016$ \\
\hline S2 & Lake Xihu, littoral zone with abundant submerged macrophytes & $53.7 "$ & 11.4" & 19 \\
\hline S3 & $\begin{array}{l}\text { Lake Xihu, littoral zone with water hyacinth (Eichhornia } \\
\text { crassipes) and abundant submerged macrophytes (same loc. as } \\
\text { W16) }\end{array}$ & N $26^{\circ} 00^{\prime} 56.1^{\prime \prime}$ & E $100^{\circ} 03^{\prime} 07.5^{\prime \prime}$ & $19-04-2016$ \\
\hline
\end{tabular}


Table 1. (cont.)

\begin{tabular}{|c|c|c|c|c|}
\hline S4 & $\begin{array}{l}\text { Lake Xihu, littoral zone with abundant submerged macrophytes } \\
\text { (same loc. as W17) }\end{array}$ & $\mathrm{N} 26^{\circ} 00^{\prime} 57.5^{\prime \prime}$ & E $100^{\circ} 03^{\prime} 09.7^{\prime \prime}$ & $19-04-2016$ \\
\hline S5 & Lake Zibi, littoral zone with abundant submerged macrophytes & $\mathrm{N} 26^{\circ} 08^{\prime} 22.5^{\prime \prime}$ & E $99^{\circ} 57^{\prime} 07.7^{\prime \prime}$ & 19-04-2016 \\
\hline S6 & Lake Zibi, littoral zone with abundant submerged macrophytes & $\mathrm{N} 26^{\circ} 08^{\prime} 23.2^{\prime \prime}$ & E $99^{\circ} 57^{\prime} 05.2^{\prime \prime}$ & 19-04-2016 \\
\hline S7 & ke Zibi, littoral zone with abundant submerged macrophytes & N $26^{\circ} 08^{\prime} 35.8^{\prime \prime}$ & Е $99^{\circ} 58^{\prime} 58.9^{\prime \prime}$ & 19-04-2016 \\
\hline S8 & ond near Lake Zibi, abundant submerged macrophytes & N $26^{\circ} 08^{\prime} 37.4^{\prime \prime}$ & E $99^{\circ} 56^{\prime} 58.0^{\prime \prime}$ & 19-04-2016 \\
\hline S9 & Lake Zibi, littoral zone with reed stands & $\mathrm{N} 26^{\circ} 08^{\prime} 50.5^{\prime \prime}$ & E $99^{\circ} 56^{\prime} 55.6^{\prime \prime}$ & $19-04-2016$ \\
\hline $\mathrm{S} 10$ & eservoir, clay shore & $\mathrm{N} 26^{\circ} 17^{\prime} 24.5^{\prime \prime}$ & E $99^{\circ} 58^{\prime} 39.7^{\prime \prime}$ & 19-04-2016 \\
\hline S11 & uhua reservoir, low clay coast with filamentous algae & $\mathrm{N} 26^{\circ} 25^{\prime} 26.2^{\prime \prime}$ & $\mathrm{E} 99^{\circ} 58^{\prime} 02.0^{\prime \prime}$ & $19-04-2016$ \\
\hline S12 & $\begin{array}{l}\text { Lake Jainhu, shallow littoral zone with submerged macrophytes } \\
\text { (same loc. as W25) }\end{array}$ & N $26^{\circ} 29^{\prime} 06.4^{\prime \prime}$ & E $99^{\circ} 56^{\prime} 36.9^{\prime \prime}$ & 20-04-2016 \\
\hline $\mathrm{S} 13$ & Lake Jainhu, open shallow littoral close to S12 & - & - & 20-04-2016 \\
\hline S14 & ervoir, clay bottom with submerged terrestrial & $\mathrm{N} 25^{\circ} 28^{\prime} 34.9^{\prime \prime}$ & $\mathrm{E} 100^{\circ} 25^{\prime} 40.2^{\prime \prime}$ & 20-04-2016 \\
\hline S15 & Fish pond & $\mathrm{N} 25^{\circ} 27^{\prime} 06.7^{\prime \prime}$ & $\mathrm{E} 100^{\circ} 34^{\prime} 06.6^{\prime \prime}$ & $20-04-2016$ \\
\hline S16 & sh pond & & E $100^{\circ} 35^{\prime} 14.7^{\prime \prime}$ & 20-04-2016 \\
\hline S17 & e, abundant submerged & - & - & 2016 \\
\hline S18 & $\begin{array}{l}\text { Pond close to Shuizhangdi lake, abundant submerged } \\
\text { macrophytes }\end{array}$ & N $25^{\circ} 26^{\prime} 15.4^{\prime \prime}$ & E $100^{\circ} 36^{\prime} 03.1^{\prime \prime}$ & 20-04-2016 \\
\hline S19 & $\begin{array}{l}\text { concrete embankment close to Shuizhangdi lake, } \\
\text { submerged macrophytes }\end{array}$ & $\mathrm{N} 2$ & $\mathrm{E} 100^{\circ} 3$ & 16 \\
\hline S20 & $\begin{array}{l}\text { Shuizhangdi lake, abundant submerged macrophytes and } \\
\text { filamentous algae }\end{array}$ & $"$ & E 1 & 20 \\
\hline S21 & Lotus & $\mathrm{N} 25^{\circ} 26^{\prime} 19.8^{\prime \prime}$ & $\mathrm{E} 100^{\circ} 35^{\prime} 33.1^{\prime \prime}$ & 2016 \\
\hline $\mathrm{S} 22$ & $\mathrm{~m}$ & $\mathrm{~N} 25^{\circ} 41^{\prime} 39.4^{\prime \prime}$ & o $38^{\prime} 49.2^{\prime \prime}$ & 2016 \\
\hline $\mathrm{S} 23$ & ho & $3 "$ & $3.2^{\prime \prime}$ & 2016 \\
\hline S24 & & 4.6" & $38^{\prime} 38.7$ & 2016 \\
\hline S25 & Same re & N $26^{\circ} 23^{\prime} 34.1^{\prime \prime}$ & E $100^{\circ} 38^{\prime} 25.9^{\prime \prime}$ & 21-04-2016 \\
\hline S26 & & & & 2016 \\
\hline S27 & & & & 016 \\
\hline S28 & & $2^{\prime \prime}$ & $33^{\prime} 47.0^{\prime \prime}$ & 21-04-2016 \\
\hline S29 & hai & $5^{\circ} 43^{\prime} 16.9^{\prime \prime}$ & E $100^{\circ} 11^{\prime} 32.1^{\prime \prime}$ & 22-04-2016 \\
\hline S30 & $\begin{array}{l}\text { Pond in agricultural area, without macrophytes (same loc. as } \\
\text { W26) }\end{array}$ & N $25^{\circ} 43^{\prime} 26.3^{\prime \prime}$ & E $100^{\circ} 10^{\prime} 54.6^{\prime \prime}$ & 22-04-2016 \\
\hline S31 & Fish pond without macrophytes (same loc. as W27). & & E $100^{\circ} 10^{\prime} 59.6^{\prime \prime}$ & 016 \\
\hline S32 & $\begin{array}{l}\text { Lake Erhai, ro } \\
\text { crassipes) and }\end{array}$ & 0" & 6" & 2016 \\
\hline S33 & $\begin{array}{l}\text { Lake Erhai, shallow littoral zone with water caltrop (Trapa sp.) } \\
\text { and abundant submerged macrophytes }\end{array}$ & 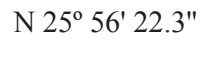 & $\mathrm{E}$ & 16 \\
\hline S34 & $\begin{array}{l}\text { Irrigation channel close to Lake Erhai, abundant submerged } \\
\text { macrophytes }\end{array}$ & N 255 56' 11.4" & E $100^{\circ} 06^{\prime} 32.3^{\prime \prime}$ & $22-04$ \\
\hline S35 & $\begin{array}{l}\text { Lake Erhai, Xi'er river mouth within Dali city, abundant } \\
\text { submerged macrophytes and filamentous algae (same loc. as W1) }\end{array}$ & 4" & $00^{\circ} 13^{\prime} 43.9^{\prime \prime}$ & 22-04-2016 \\
\hline S36 & $\begin{array}{l}\text { Lake Erhai, stone embankment within Dali city, abundant } \\
\text { submerged macrophytes and filamentous algae (same loc. as W2) }\end{array}$ & N $25^{\circ} 36^{\prime} 26.7^{\prime \prime}$ & E $100^{\circ} 14^{\prime} 27.8^{\prime \prime}$ & 22-04-2016 \\
\hline S37 & $\begin{array}{l}\text { Decorative pond within Dali city, with rock bottom without } \\
\text { macrophytes (same loc. as W3) }\end{array}$ & $\mathrm{N}$ & E $100^{\circ} 15^{\prime}$ & 2016 \\
\hline S38 & $\begin{array}{l}\text { Lake Erhai, open rocky littoral, filamentous algae on stones } \\
\text { (same loc. as W5) }\end{array}$ & N 253' $52.9^{\prime \prime}$ & E $100^{\circ} 16^{\prime} 52.6^{\prime \prime}$ & 22-04-2016 \\
\hline S3 & $\begin{array}{l}\text { Lake Erhai, bay separated by stone pier, abundant submerged } \\
\text { macrophytes, filamentous algae on stones }\end{array}$ & 4 & E $100^{\circ} 16^{\prime} 24.8^{\prime \prime}$ & 6 \\
\hline S40 & $\begin{array}{l}\text { Lake Erhai, open rocky littoral, filamentous algae on stones } \\
\text { (same loc. as W7) }\end{array}$ & $\mathrm{N} 25^{\circ} 44^{\prime} 00.7^{\prime \prime}$ & E $100^{\circ} 13^{\prime} 56.3^{\prime \prime}$ & 22-04-2016 \\
\hline
\end{tabular}


substrate-associated. We did not find Bosmina coregoni, which is present in pelagic zone of Lake Erhai across the year according to Yang et al. (2014), probably because we collected only shore samples.

In winter, most frequent littoral species in the area were Chydorus cf. sphaericus and Flavalona costata. Other common species were Disparalona chappiuisi, Camptocercus uncinatus and Coronatella rectangula. In spring, all these species remain common, Chydorus cf. spahaericus and Coronatella rectangula being most frequent, and two more species, Simocephalus mixtus and Pleuroxus quasidenticulatus became common as well. Among planktonic species, Bosmina longirostris was most common during both winter and spring.

\section{Family Sididae}

Sida ortiva Korovchinsky, 1979. Littoral species, associated with vegetation; specimens are able to attach to a substrate. Common in the area in both winter and spring, found in vegetated areas of Lake Erhai, lake Xihu and Lake Jianghu, Zibi reservoir and in ponds. East Asian species, distributed from East Siberia to Bangladesh and South Vietnam (Korovchinsky, 2004). A first record for Yunnan province. Earlier records of Sida crystallina (O. F. Müller, 1776) from South-East China, including Yunnan (Chiang \& $\mathrm{Du}, 1979$ ) probably all belong to $S$. ortiva (see Korovchinsky, 2004). For description, see Korovchinsky (2004), and Kotov et al., (2012).

\section{Family Daphniidae}

Ceriodaphania dubia Richard, 1894. Planktonic species, found only in Lake Erhai in winter (loc. W2, W6, W7). Widely distributed Palearctic species, rare in China, with few records in Taiwan, Wuhan, Jiangxi, Yunnan (Xiang et al., 2015), and in Xinjiang (Chertoprud et al., 2017). Studied specimens (Fig. 1A-C) share diagnostic characters of Palearctic populations. For description of European populations, see Hudec (2010).

Ceriodaphnia quadrangula (O.F. Müller, 1785). Planktonic species, rare in the area, found in Erhai in winter and spring (loc. W11, W12,
S29) and in Zibi in spring only (loc. S7). Widely distributed Palearctic species, common in China (Xiang et al., 2015). Recorded for Dali Area by $\mathrm{Lu}$ (1939). For description of European populations, see Hudec (2010)

Ceriodaphnia reticulata (Jurine, 1820). Planktonic species. Found only in Lake Chenghai in spring. Widely distributed Palearctic species, rare in China, recorded mostly in mountainous areas (Tibet, Xinjiang, Yunnan, Gansu and Qinghai provinces), and in Nanjing, Jiangsu (Xiang et $a l ., 2015)$ but, in our opinion, the latter record is doubtful. For description of European populations, see Hudec (2010).

Daphnia (Daphnia) galeata Sars, 1864. Pelagic planktonic species, found in Lake Erhai, Lake Xihu, and Lake Shuizhangdi, in open water samples. Common Palearctic species. According to Xiang et al. (2015), common in large lakes and reservoirs of China, including Yunnan, and almost the only pelagic Daphnia in Southern China, reaching the island of Hainan in the South. For Yunnan, taxonomic status of $D$. galeata from Lake Dianchi was confirmed by genetical studies (Ma et al., 2015). Record of D. hyalina from Erhai (Lu, 1939) probably belongs to $D$. galeata instead. For description, see Benzie (2005).

Daphnia (Daphnia) pulex Leydig, 1860. Planktonic species, inhabiting small water bodies and vegetated coastal areas. Rare in the area, found in winter only in Erhai (loc. W1) and Xihu (loc. W16), both locations are characterized by abundant submerged macrophytes. Palearctic species, so far recorded mostly in North and Central China, records in South-East China rare (see Xiang et al., 2015). For description, see Benzie (2005).

Daphnia (Ctenodaphnia) sinensis $\mathrm{Gu}, \mathrm{Xu}, \mathrm{Li}$, Dumont, Han, 2013. Planktonic species inhabiting mostly small water bodies. Rare in the area, found in winter in one locality in Lake Erhai (loc. W2). Species is widely distributed in Asia and Africa (see Popova et al., 2016), was recorded from China as D. similis and D. similoides, both these species are not present in the region (Popova et al., 2016). For description, see Popova et al. (2016).

Scapholeberis kingi Sars, 1888. Littoral species associated with water surface. Found in a single locality, a pond in agricultural area Lake 
Table 2. Distribution of cladocera species in Dali area in winter 2015 and spring 2016. Abbreviations: W, winter samples; S, spring samples; EastAs, East Asian species; PaleoTr, Paleotropical; PanTr, Pantropical; PaleAr, Palearctic; SC, probable species-complex; WD, widely distributed or cosmopolitan. Distribución de las especies de cladóceros en la zona de Dali en invierno de 2015 y primavera de 2016. Abreviaturas: W, muestras de invierno; S, muestras de primavera; EastAs, especies del Este asiático; PaleoTr, Paleotropical; PanTr, Pantropical; PaleAr, Paleártica; SC, probable complejo de especies; WD, especie cosmopolita o ampliamente distribuida.

\begin{tabular}{|c|c|c|c|c|c|c|c|c|c|c|c|c|c|c|c|c|c|}
\hline \multirow{2}{*}{ Time of sampling } & \multirow[t]{2}{*}{ 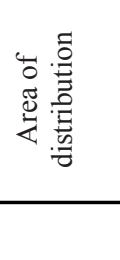 } & \multicolumn{2}{|c|}{ 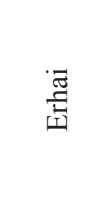 } & \multicolumn{2}{|c|}{$\begin{array}{l}\vec{\Xi} \\
\bar{x}\end{array}$} & \multicolumn{2}{|c|}{$\overrightarrow{\stackrel{0}{N}}$} & \multicolumn{2}{|c|}{ 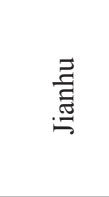 } & \multirow{2}{*}{ 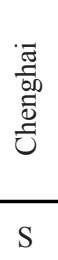 } & \multirow{2}{*}{ 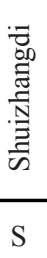 } & \multicolumn{2}{|c|}{ 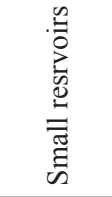 } & \multicolumn{2}{|c|}{$\begin{array}{l}\text { है } \\
\text { ¿ }\end{array}$} & \multirow{2}{*}{ 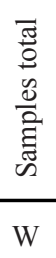 } & \multirow{2}{*}{ 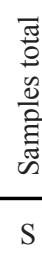 } \\
\hline & & W & $\mathrm{S}$ & $\mathrm{W}$ & $\mathrm{S}$ & W & $\mathrm{S}$ & W & $\mathrm{S}$ & & & W & $\mathrm{S}$ & W & $\mathrm{S}$ & & \\
\hline Sida ortiva & EastAs & + & + & + & & + & + & + & & & & & & + & + & 7 & 7 \\
\hline Ceriodaphnia dubia & PaleAr & + & & & & & & & & & & & & & & 3 & 0 \\
\hline Ceriodaphnia quadrangula & PaleAr & + & + & & & & + & & & & & & & & & 2 & 2 \\
\hline Ceriodaphnia reticulata & PaleAr & & & & & & & & & + & & & & & & 0 & 1 \\
\hline Daphnia galeata & PaleAr & + & + & + & & & & & + & & + & + & + & & & 7 & 4 \\
\hline Daphnia pulex & PaleAr & + & & & & & & & & & & & & & & 2 & 0 \\
\hline Daphnia sinensis & WD & + & & & & & & & & & & & & & & 1 & 0 \\
\hline Scapholeberis kingi & PaleoTr & & & & & & & & & & & & & + & + & 1 & 1 \\
\hline Simocephalus congener & WD & + & & & & & & & & & & & & & & 2 & 0 \\
\hline Simocephalus expinosus & WD & + & & & & & & & & & & & & & & 1 & 0 \\
\hline Simocephalus mixtus & WD & + & + & + & & + & + & & & & + & + & & + & + & 9 & 14 \\
\hline Simocephalus serrulatus & WD & + & + & + & & + & + & & & & + & & & & ${ }^{\top}$ & 4 & 9 \\
\hline Macrothrix spinosa & PaleoTr & + & & & & & & & & & & & & & & 1 & 0 \\
\hline Ilyocryptus spinifer & WD & + & & & & & & & & & & & & & & 3 & 0 \\
\hline Ilyocryptus cuneatus & PaleAr & & & & & & & & & & & & + & & & 0 & 1 \\
\hline Alona affinis & PaleAr & & + & & & & & & & & & & & + & + & 1 & 2 \\
\hline Alona guttata & $\mathrm{WD}, \mathrm{SC}$ & + & + & & & & + & & & & & + & & + & + & 4 & 3 \\
\hline Alona kotovi & EastAs & + & & & & & & & & & & & & & & 3 & 0 \\
\hline Anthalona harti & PaleoTr & + & & & & & & & & & & & & & & 1 & 0 \\
\hline Camptocercus uncinatus & PaleAr & + & + & + & + & + & + & & & & & & + & & & 10 & 10 \\
\hline Coronatella rectangula & PaleAr & + & + & + & + & & + & + & & & + & + & + & + & + & 11 & 23 \\
\hline Flavalona costata & PaleAr & + & + & + & + & + & + & + & & & & + & + & + & + & 20 & 17 \\
\hline Graptoleberis testudinaria & WD, SC & + & + & & + & + & + & & & & & & & & + & 3 & 8 \\
\hline Leydigia ciliata & PaleoTr & & + & & & & & & & + & & & & & & 0 & 2 \\
\hline Oxyurella tenuicaudis & PaleAr & + & & & & & & & & & & & & & & 1 & 0 \\
\hline Alonella excisa & WD, SC & + & + & & & & & + & & & & & & & & 2 & 1 \\
\hline Chydorus cf. sphaericus & $\mathrm{WD}, \mathrm{SC}$ & + & + & + & + & + & + & + & + & + & + & + & & + & + & 27 & 25 \\
\hline Disparalona chappuisi & PaleoTr & + & + & + & + & + & + & + & + & & & & & + & + & 10 & 15 \\
\hline Dispralona ikarus & EastAs & & + & & & & & & & & & & + & & & 0 & 2 \\
\hline Pleuroxus aduncus & PaleAr & + & + & & + & & & & & & & & & & + & 2 & 5 \\
\hline Pleuroxus laevis & PaleAr & + & & & & & & & & & & & & & & 5 & 0 \\
\hline Pleuroxus quasidenticulatus & PaleoTr & + & + & + & + & & + & & & + & & & + & + & + & 6 & 11 \\
\hline Pseudochydorus bopingi & EastAs & + & + & & & & + & & & + & & & + & & & 3 & 6 \\
\hline Bosmina longirostris & $\mathrm{WD}, \mathrm{SC}$ & + & + & & + & + & + & + & + & & & + & + & & + & 11 & 10 \\
\hline Total number of species & & & & & & & & & & 5 & 5 & & & & & & \\
\hline
\end{tabular}


Erhai in both winter and spring (loc. W26, S30). Paleotropical species, described from Australia (Dumont \& Pensaert, 1983). Common in China (Xiang et al., 2015). For description, see Dumont \& Pensaert (1983).

Simocephalus (Echinocaudus) congener (Koch, 1841). Littoral species, associated with vegetation; specimens are able to attach to substrate. Several specimens found in Lake Erhai (loc. W9) in winter. Species inhabit Central and Eastern Europe and Siberia (Orlova-Bienkowskaya, 2001). Recorded for China only in Potatso National Park in Shangri-La (Xiang et al., 2015) and in Manning reservoir on Hainan Island (Sinev et al., 2015). This species is close to $S$. expinosus. According to Orlova-Bienkowskaya (2001), it is a separate species which differs from $S$. expinosus by the morphology of the postabdominal claw, having a pecten of 18-22 spines on the outer side instead of 8-12 in S. expinosus. However, in reality, such conclusions must be checked, as the species diagnosed by Orlova-Bienkowskaia (2001) is open to criticism (Huang et al., 2014).

Simocephalus (Echinocaudus) expinosus (De Geer, 1778). Littoral species, associated with vegetation; specimens are able to attach to substrate. Rare in the area, few specimens found in Lake Erhai (loc. W29) in winter. Distributed in West Hemisphere (Orlova-Bienkowskaia, 2001); for list of locations in China see Xiang et al. (2015). For description, see Orlova-Bienkowskaia (2001).

Simocephalus (Simocephalus) mixtus (O. F. Müeller, 1776). Littoral species, associated with vegetation; specimens are able to attach to substrate. Most common species in the area, found in vegetated areas of lakes and ponds in both winter and spring. Widely distributed species, recorded in all climatic zones of North Hemisphere (Orlova-Bienkowskaia, 2001), common on Hainan Island (Sinev et al., 2015), but in continental China recorded only once, in Heilongjiang Province (Xiang et al., 2015). Possibly confused with its sibling-species, $S$. vetulus and $S$. vetuloides, and being identification based on the key by Orlova-Bienkowskaia (2001) vulnerable to criticism (Huang et al., 2014).

Simocephalus (Coronocephalus) serrulatus
(Koch, 1841). A littoral species, associated with vegetation; specimens capable to attach to the substrate. Common species in the area, found in vegetated areas of lakes and ponds in both winter and spring. Cosmopolitan species, common in the Oriental region (Orlova-Bienkowskaia, 2001), widely distributed but rare in China (Xiang et al., 2015). For a description see Orlova-Bienkowskaia (2001).

\section{Family Ilyocryptidae}

Ilyocryptus cuneatus Śtifter, 1988. Benthic, associated with muddy or clayey bottom. Rare in the area, found in a single small reservoir in spring (loc. S23). Palearctic species; in Asia recorded for Asian Russia and Japan (Kotov \& Śtifter, 2006). The first record for China, and also southernmost record for the species. Distinctive characters of species includes retained valves from previous molt (Fig. 1D); setae on posterior margin of valves with distinctive spine-like setules one side in its basal portion (Fig. 1E); postabdomen with anus opening at the middle (Fig. 1F); preanal margin of postabdomen with doubled spines and no setules near their bases (Fig. 1G); and postbadominal claw with long ventral setules at the base (Fig. 1F). For detailed description, see Kotov \& Śtifter (2006).

Ilyocryptus spinifer Herrick, 1882. Benthic, associated with mud or clay bottom. Rare in the area, found only in winter in Lake Erhai (W7, W11) and in a temporary pool in agricultural area (W13). No evidence of the non-cosmopolitanism of this species has been found (Kotov \& Dumont, 2000); common in the Oriental region, including China. For list of records in China, see Xiang et al. (2015). For detailed description see Kotov \& Dumont (2000) and Kotov et al. (2012) for Far Eastern populations.

\section{Family Macrothricidae Norman \& Brady, 1867}

Macrothrix spinosa King, 1853. Littoral species, associated with vegetation. Rare in the area; several specimens found in Lake Erhai in winter (loc. W2). Species presumed to be Pantropical (Smirnov, 1992), common in the Oriental region. Common in South-East China (Ji et al., 2015). 

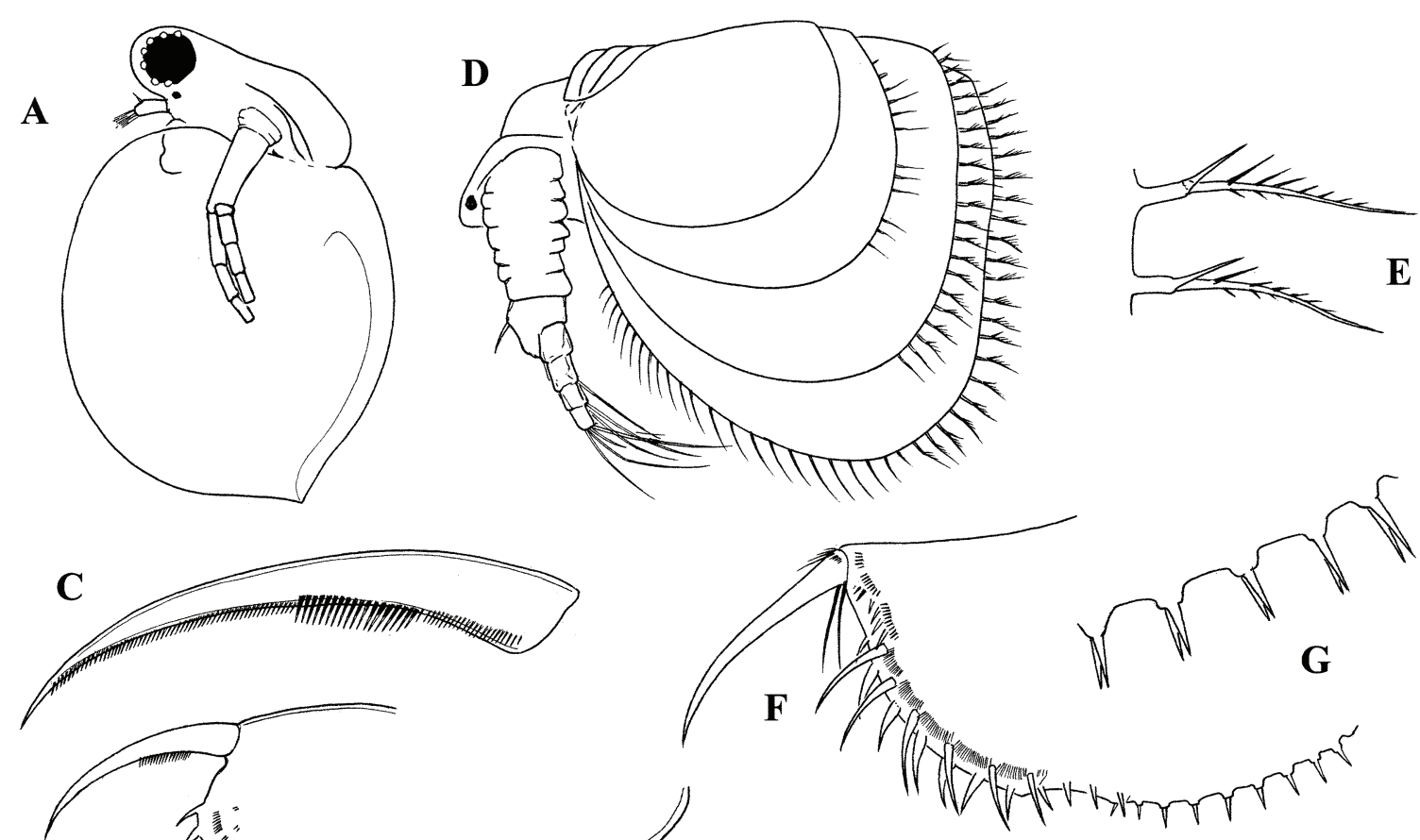

B

咅"
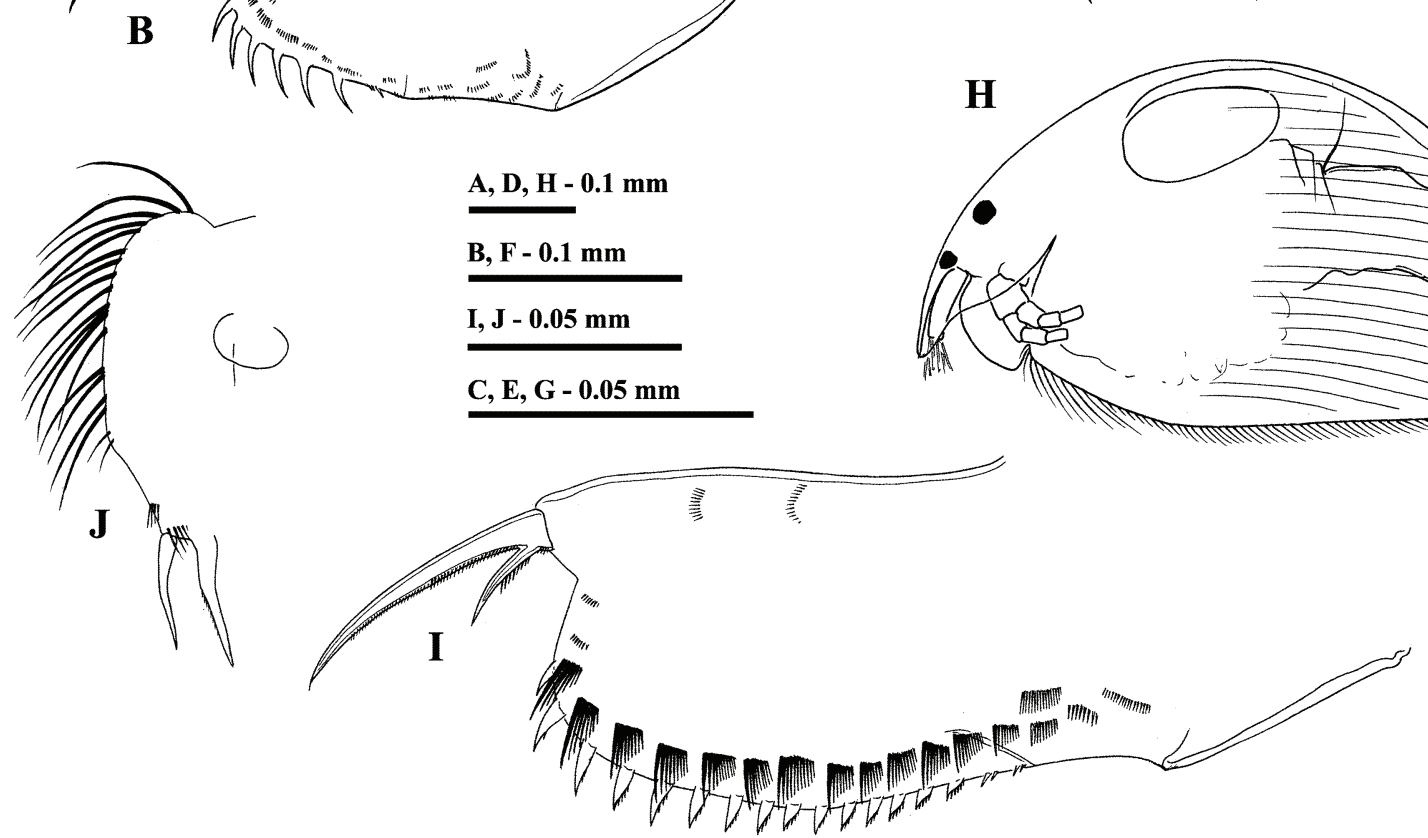

Figure 1. A-C, Ceriodaphania dubia Richard, 1894 from Lake Erhai (loc. W2), parthenogenetic female. A, lateral view. B, postabdomen. C, postabdominal claw. D-G, Ilyoryptus cuneatus Śtifter, 1988 from reservoir in Dali area (loc. S 23), parthenogenetic female. D, lateral view. E, setae of posterior margin of valves. F, postabdomen. G, spines on preanal margin of postabdomen. H-J, Alona kotovi Sinev, 2012 from Lake Erhai (loc. W11), parthenogenetic female. H, lateral view. I, anterior margin of thoracic limb I. Ceriodaphania dubia Richard, 1894 del lago Erhai (loc. W2), hembra partenogenética. A, vista lateral B, postabdomen. C, pinza postabdominal. D-G, Ilyoryptus cuneatus Śtifter, 1988 del embalse en la zona de Dali (loc. S 23), hembre partenogenética. D, vista lateral. E, seta del margen posterior de las valvas. F, postabdomen. G, espines del margen preanal del postabdomen. H-J, Alona kotovi Sinev, 2012 del lago Erhai (loc. W11), hembra partenogenética. H, vista lateral. I, margen anterior del limbo torácico I. 
For description, see Smirnov (1992) and Hollwedel et al. (2003); for description of Indochina populations see Idris (1983).

\section{Family Chydoridae, subfamily Aloninae}

Alona affinis (Leydig, 1860). Littoral species, inhabiting both vegetated and open littoral zone. Rare in the area, found in decorative pond in Dali city in both spring and winter (loc. W3, S37), and in one location in Lake Erhai in spring (S35). Common widely distributed Palearctic species, also recorded in South Africa (Sinev, 2009). Common in China, recorded for Yunnan (Ji et al., 2015). For description, see Alonso (1996) and Sinev (2009).

Alona guttata Sars, 1862. Littoral species, associated with vegetation. Found in Lake Erhai and in single pond in both winter and spring, in Lake Zibi and smaller reservoirs in spring (loc. W3, W8, W10, W31, S6, S35, S37), never abundant. Species presumed to be cosmopolitan; recent studies of Mexican populations revealed no significant differences from European specimens (Sinev \& Silva-Briano, 2012). Common in China (Ji et al., 2015), recorded for Erhai by Lu (1939). For detailed description, see Alonso (1996).

Alona kotovi Sinev, 2012. Rare littoral species, associated with muddy or clay bottom, found in Lake Erhai in winter only (loc. W10, W11, W29). Species described from Vietnam, and recently recorded from Korea (Jeong et al., 2014) and Hainan Island (Sinev et al., 2015). first record of the species for continental China. The only Oriental species of the quadrangularis-group (Sinev, 2012, 2016) its area of distribution probably includes India, South-East Asia and South China where it was confused with Palearctic A. quadrangularis (O.F. Müller, 1776). Studied specimens (Fig. 1H) share all diagnostic features of $A$. kotovi, including postabdomen with only weakly convex postanal margin (Fig. 1I), and over 12 large setules on anterior margin of thoracic limb I (Fig. 1J) instead of 7-8 in Alona quadrangularis s. str. For description, see Sinev (2012).

Anthalona harti harti Van Damme, Sinev \& Dumont, 2011. Littoral species, associated with macrophytes. Several specimens in Lake Erhai in winter (loc. W2), among macrophytes. For detailed descriptions see Van Damme et al. (2011), for description of Indochina populations see Sinev \& Kotov (2012). The first record for Yunnan province. Distributed in tropical Asia, Mediterranean region, and Africa (Van Damme et al., 2011, Sinev \& Kotov, 2012). Recorded for China mostly as Alona verrucosa Sars, 1901 (Ji et al., 2015).

Camptocercus uncinatus Smirnov, 1971. Littoral species, rather common in Lake Erhai, Lake Xihu and Lake Zibi in both winter and spring; in all lakes among macrophytes and on rocks with filamentous algae. C. uncinatus is distributed in southern Europe, Israel, Iraq, Egypt, Ethiopia, Rift Valley of Africa, South-West and East Siberia and Korea (Sinev, 2014). It was recently recorded in Hainan (Sinev et al., 2015). In China, the most frequently reported species of Camptocercus is Camptocercus australis Sars, 1988 (Ji et al., 2015) but this species is confined to Australia (Sinev, 2015) and all these records most probably belong to $C$. uncinatus as well. Records of subfossil C. rectirostris from Erhai (Lu et al., 2016) probably belong to $C$. uncinatus. For description see Sinev (2014), for description of East Asian populations see Kotov et al. (2012).

Coronatella rectangula (Sars, 1862) $(=$ Alona rectangula Sars, 1862). Littoral species, associated with macrophytes, common in both winter and spring in most water bodies. C. rectangula is a common Palaearctic species, distributed from Spain to Far East of Russia, common in China. In East Asia, the species penetrates South up to Peninsular Malaysia and Borneo, but South-East Asian populations slightly differs from Palearctic by narrower postabdomen, probably presenting species-complex (Sinev \& Yusoff, 2015; Sinev et al., 2015). Common in China, including Yunnan (Ji et al., 2015), recorded for Lake Erhai (Lu, 1939). For description, see Van Damme \& Dumont (2008).

Parthenogenetic females from Dali area (Fig. 2A) have morphology typical for Palearctic populations, with relatively broad postabdomen (Fig. 2B). Inner distal lobe of limb I (Fig. 2C) with rudimentary seta 1 seta 2 curved, claw-like, with two thin spines at the middle and thin posterior portion armed with thin setules, seta 3 thick, 

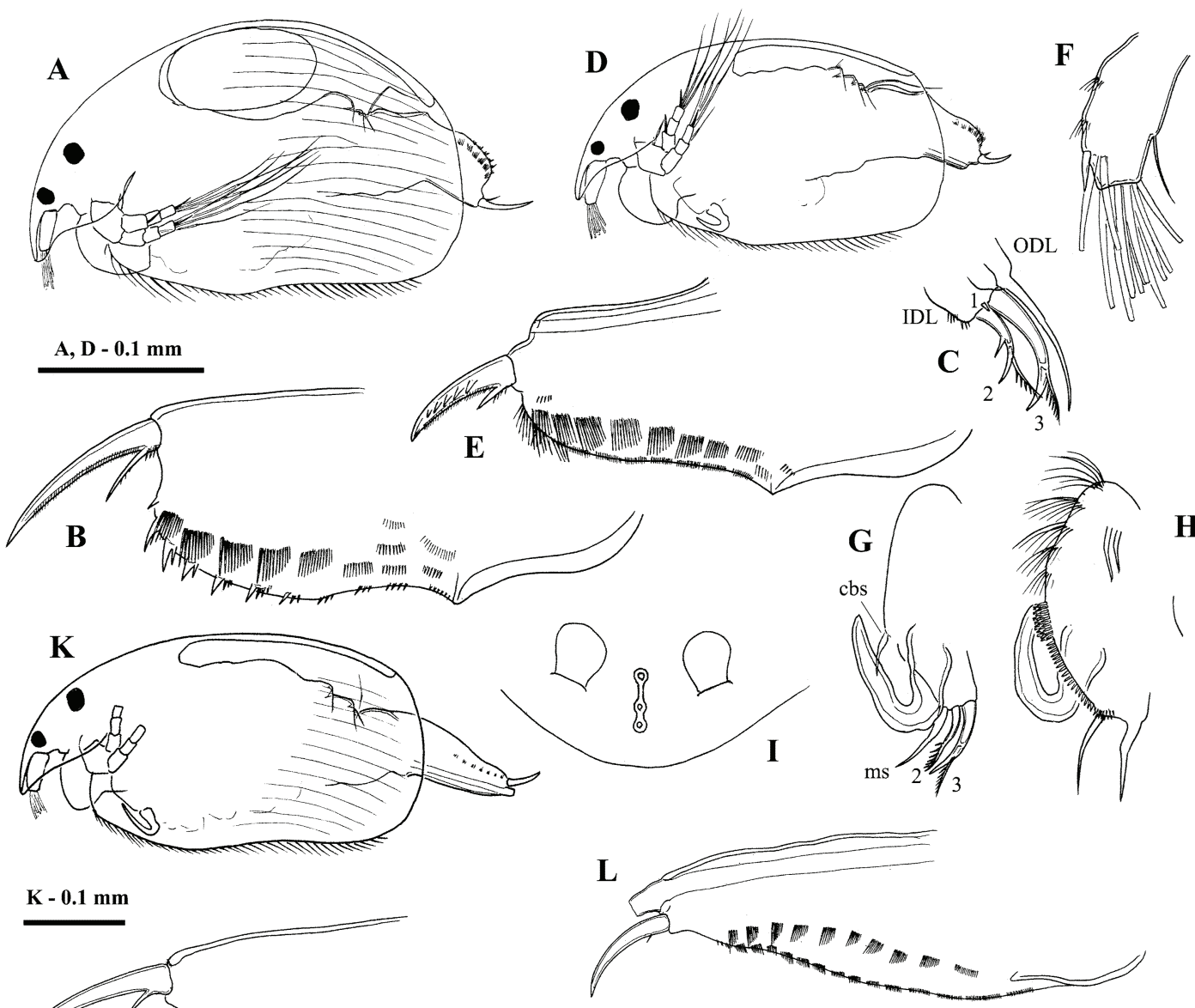

$\mathbf{L}$
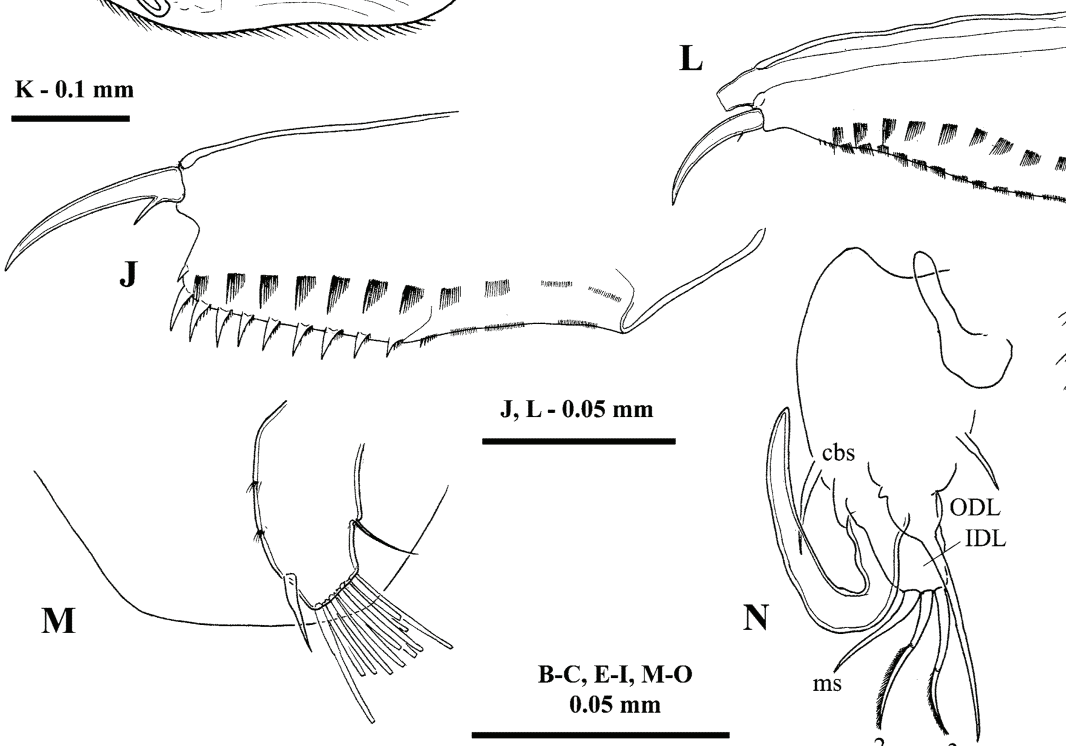

J, L - 0.05 mm
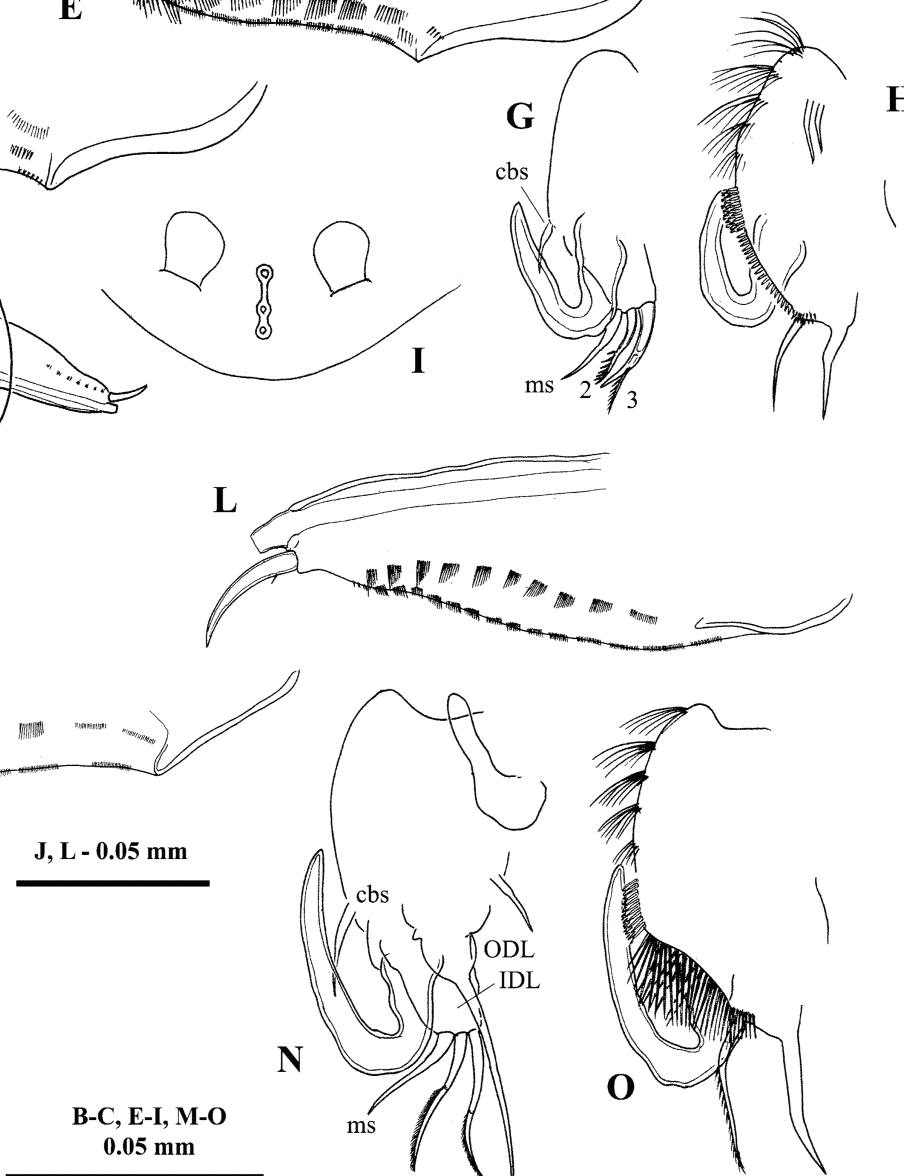

H
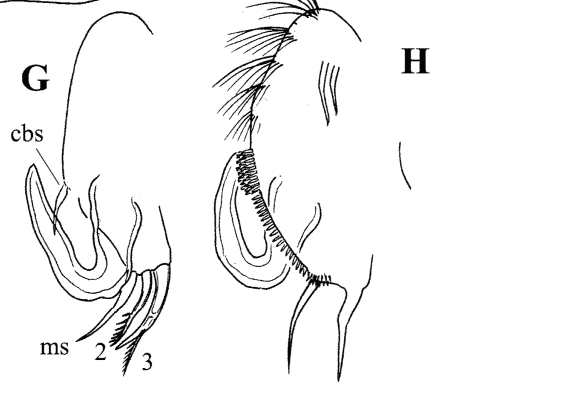
curved, claw-like, with single thick spine at the middle and thin posterior portion armed with setule; seta 2 shorter and two times thinner than seta 3 , seta 3 slightly longer than outer distal lobe seta. Morphology of males from East Asian population were never studied in detail, so full description is provided.

Male. Body (Fig. 2D) low oval, height-length ratio about 0.6. Ocellus and eye are of the similar size as in female, eye two times larger than the ocellus.

Postabdomen (Fig. 2E) is short, of moderate width, with subrectangular distal portion. Ventral margin almost straight. Gonopores located at the end of postabdomen. Distal margin almost straight, distal angle broadly rounded. Postanal and anal margin almost straight. Distal part of postabdomen 1.5 times longer than preanal part; anal and postanal portion of similar length. Postanal angle not defined, preanal angle well-defined, prominent. Clusters of short setules in place of marginal denticles, lateral fascicles of setules similar to those of female, but distal setule in each fascicle thinner, of similar thickness as the others. Postabdominal claw short, about $2 / 3$ length of postanal margin, weakly curved, with short thick basal spine about 1/4 length of claw itself. There are 4-5 thick short spines on inner side of claw, these spines are not present in other species of Coronatella.

Antennule (Fig. 2F) moderately long, length about 2.5 widths. Male seta short, arising at $3 / 4$ distance from the base and reaching to the end of antennule. Two lateral and ten terminal aesthetascs, longest of them slightly shorter than antennule itself. All aesthetascs projecting beyond anterior margin of the head shield. Thoracic limb I (Fig. 2G-H) with short U-shaped copulatory hook two times shorter than limb itself. Copulatory brush present; copulatory brush seta short. Ventral face of limb below them with about 20 short thick setules. Inner distal lobe without seta 1; setae 2 and 3 much shorter and thinner than in female; seta 2 slender, without any spines at the middle, distal portion armed with thin setules; seta 3 moderately thick, curved, with single spine at the middle and thin posterior portion armed with thin setules, longer than seta 2; male seta curved, shorter than seta 3 .
Morphology of males fully agrees with earlier descriptions (Frey 1988a; Alonso, 1996; Van Damme \& Dumont 2008) with one exception lateral aesthetascs on antennulae were never reported for males of C. rectangula. Due to small size of the animal it is unclear if they were overlooked in previous studies or are present only in studied population.

Flavalona costata (Sars, 1962) (former Alona costata Sars, 1862). Littoral species, associated with macrophytes, common in both winter and spring in most water bodies. Palearctic species, in East Asia penetrating South to the Hainan Island and North-East Thailand (Sinev, 2016). Common in China, including Yunnan (Ji et al., 2015), recorded for Lake Erhai by $\mathrm{Lu}$ (1939). Studied females have typical for the species morphology of postabdomen (Fig. 2J) and head pores (Fig 2I), with length of lateral head pores about half distance between anterior and posterior main head pores, and with rounded lateral head pore pockets. Ephippial females were found in Lake Erhai in winter (loc. W10) and in small reservoir and fish pond in spring (loc S.14, S15). Males of $F$. costata are rarely recorded for East Asian populations, so their full description is provided.

Body (Fig. 2K) low oval, dorsal margin only weakly convex. Maximum height at the middle of the body, height/length ratio c. 0.55 . Ocellus smaller than eye. Rostrum short, slightly truncated (Fig. 2M).

Postabdomen (Fig. 2L) moderately long, narrowing distally in postanal part. Ventral margin wavy in studied specimens. Basis of claws bordered from distal margin by clear incision. Genital process short, about 1/4-1/3 length of postabdominal claw. Distal margin very short, distal angle obtuse. Dorsal margin convex in anal portion, straight in postanal portion. Preanal and postanal angles not defined. Clusters of short setules in place of marginal denticles, distalmost cluster consisting of 3-5 thick short setules. Lateral fascicles as in female. Postabdominal claw slightly longer than preanal portion of postabdomen, curved. Basal spine short and thin, visible only under oil immersion.

Antennule (Fig. 2M) with 12 terminal aesthetascs, longest about 3/4 length of anten- 
nule. Male seta arising at 1/4 length from tip, about $1 / 3$ length of antennule. Thoracic limb I (Fig. 2N-O) with U-shaped copulatory hook, two times shorter than limb itself. IDL with three setae. IDL setae 2 and 3 thin, of similar length. Male seta curved, shorter than seta 2 . Copulatory brush seta about 2/3 length of IDL seta 2 . Ventral face of the limb under the copulatory brush with row of about 20 long stiff setules.

Morphology of males fully agree with the previous descriptions of European populations of the species (Alonso, 1996; Sinev, 1999; Hudec, 2010; Sinev \& Dumont, 2016). For detailed description see Sinev \& Dumont (2016).

Graptoleberis testudinaria (Fischer,1851). Littoral species, associated with macrophytes with submerged leaves. Uncommon in the area, found in Erhai, $\mathrm{Xi} \mathrm{Hu}$ and Zibi, and in some ponds, more frequent in spring. Species recorded worldwide, but probably composes a species-complex, common in China ( $\mathrm{Ji}$ et al., 2015), recorded for Lake Erhai by Lu (1939). For description of European populations, see Alonso (1996), Hudec (2010).

Leydigia ciliata Gauthier, 1939. Benthic species, associated with muddy or clay bottom. Found in Erhai and Chianghai lakes in spring only. Known in Africa, tropical Asia, common in Oriental region (Kotov, 2009). Common in China (Ji et al., 2015). For detailed description, see Kotov et al. (2003).

Oxyurella tenuicaudis (Sars, 1862). Littoral species, associated with vegetation. Rare in the area; few specimens in Lake Erhai in winter (loc. W6). Widely distributed Palearctic species; frequently recorded in China, including Yunnan; southmost records in Guangdong province ( $\mathrm{Ji}$ et al., 2015), but, according to these authors, some records, especially from South China, can be erroneous. Not found in Hainan Island (Sinev et al., 2015), where it is substituted by tropical species Oxyurella singelansis. For description, see Alonso (1996) and Hudec (2010).

\section{Family Chydoridae, subfamily Chydorinae}

Alonella excisa (Fisher, 1854). Littoral species, associated with vegetation. Rare in the area, several specimens found in Lake Erhai once in winter (W6) and once in spring (loc. S32), and in Lake Jainhu in winter (loc. W25). Common in China, including Yunnan (Ji et al., 2015), recorded for Lake Erhai by Lu (1939). The species presumed to be cosmopolite (Smirnov, 1996). For description, see Alonso (1996).

Chydorus sphaericus (O.F. Müller, 1776) s. lato. Eurybiotic littoral species, sometimes encountered in pelagic zone. The most common species in the area, found in all types of water bodies in littoral samples. Chydorus sphaericus $\mathrm{s}$. lato in Eurasia is a complex of species with identical morphology of parthenogenetic females (Belyaeva \& Taylor, 2009; Klimovsky \& Kotov, 2015; Kotov et al., 2016). Chydorus sphaericus s. lato is common in China, including Yunnan (Ji et al., 2015), recorded for Lake Erhai by Lu (1939). Two ephippial females were found in Lake Erhai in winter (loc. W11). These specimens had ephippia with single egg, typical for most species of $C$. sphaericus group, while two species of the group found in North-East Palearctic, C. belyaevi Klimovsky \& Kotov, 2015 and C. cf. biovatus Frey, 1985 have ephippia with two eggs (Klimovsky \& Kotov, 2015).

Disparalona (Disparalona) ikarus Kotov \& Sinev, 2011. Species associated with open littoral. Rare, in spring in Lake Erhai (loc. S40) and two small reservoirs (loc. S14, S25). Species so far is known from Amur river basin in Russia, South Korea and Hainan Island (Kotov \& Sinev, 2011; Kotov et al., 2012; Sinev et al., 2015). It is the first record of the species in continental China. For description, see Kotov \& Sinev (2011) and Kotov et al. (2012).

Disparalona (Mixopleuroxus) chappuisi Brehm, 1934. Littoral substrate-associated species. Common, encountered in most water bodies in both spring and winter, more abundant among macrophytes. Species known from Africa and tropical Asia, in East Asia penetrating north to Far East of Russia (Neretina et al., 2018). Population of D. chappuisi from East and South-East Asia, including these from China (see Ji et al., 2015; Sinev et al., 2015) were recorded as D. hamata Birge, 1879 , but recent revision clarified its status (Neretina et al., 2018). For detailed description see Neretina et al. (2018).

Pleuroxus (Pleuroxus) aduncus (Jurine, 
1820). Littoral species, associated with vegetation. Uncommon, found in vegetated areas of Lake Erhai in both winter (loc. W12, W28) and spring (loc. S29, S32, S33), in spring also found in Lake Xihu (loc. S3) and fish ponds (loc. W15). The species was considered cosmopolitan (Smirnov, 1996), but its absence in South Hemisphere was proved recently (Smirnov et al., 2006). Common in China, but some records, especially from South part, can be unreliable (Ji et al., 2015); recorded for Erhai by Lu (1939). Dali area is a one of Southmost sure records for the species. For description, see Smirnov (1996) and Frey (1991).

Pleuroxus (Picripleuroxus) laevis Sars, 1862. Rare littoral species, associated with vegetation, found in winter in five locations in Lake Erhai only (loc. W1, W7, W9, W13, W29), absent in spring. Palearctic species (Smirnov, 1996). Common in China, including Yunnan (Ji et al., 2015). The first record for Dali Area. For description see Smirnov (1996) and Frey (1988b).

Pleuroxus (Picripleuroxus) quasidenticulatus (Smirnov, 1996). Littoral substrate-associated species. Most common species of Pleuroxus here, found mostly among macrophytes, but also on open littoral; in Erhai, Xi Hu, Zibi and Chianghai lakes and in various ponds, common and abundant in spring, infrequent in winter. recorded frpm Australia, Iran, South-East Asia, China, Korea and Far East of Russia (Smirnov, 1996; Sinev \& Korovchinsky, 2013; Sinev \& Sanoamuang, 2013; Kotov et al., 2017). For description, see Sinev \& Sanaomuang (2013).

Pseudochydorus bopingi Sinev, Garibian \& $\mathrm{Gu}, 2016$. Littoral species, feeding on the bodies of dead microcrustaceans. Found in limited numbers (several specimens per sample) in samples with abundant littoral cladocera, in Lake Erhai in both winter and spring, and in Zibi, Chianghai and two smaller reservoirs (loc. S14, S25) in spring. The species was recorded in South Vietnam, Hainan Island, Hunan and Hubei provinces of China (Sinev et al., 2016). The first record for Yunnan. Earlier Pseudochydorus records from China were attributed to $P$. globosus (et al., 2015), but all populations from South-East China probably belong to $P$. bopingi. For description, see Sinev et al. (2016).

\section{Family Bosminidae}

Bosmina (Bosmina) longirostris (O. F. Müller, 1776). Pelagic plankton species. Common in the area, found in most large water bodies in the area and in some ponds, more frequent in spring. Recorded worldwide, according to Chatterjee et al. (2013), who refer to unpublished genetic data of Taylor and Kotov, one of the few truly cosmopolitan cladocera. Common in China, including Yunnan (Xiang et al., 2015). For description see Alonso (1996).

\section{DISCUSSION}

Among the 34 species found in the area, 31 were present in Lake Erhai and 8 of were found only in Lake Erhai (see Table 1). In our opinion, this reflects a higher diversity of biotopes in the lake, for example, clusters of water caltrop and open rocky littoral exists there, while these are not present in other lakes. Number of species in two intensively sampled lakes, Xihu and Zibi, was low, only 14 species in each. Three other large lakes, Jianhu, Chenghai, Shuizhangdi, were sampled less intensively, and their diversity probably underestimated. Only 13 species were found in the ponds, and only 11 in various reservoirs with severe water fluctuations.

Lake Erhai region winter-spring fauna is conspicuous by the absence of several common groups of Cladocera, including the genera Diaphanosoma and Moina, both quite common in Central Yunnan, including Kunming area. Kunming area was sampled by the authors at the same time as Dali Area, and at least two species of Moina and three species of Diaphanosoma were present in the area, being dominating in many samples. The only species of Diaphanosoma recorded in Dali Area is Diaphanosoma brachyurum, present in Lake Erhai pelagic zone in Jule-November (Yang et al., 2014). Diaphanosoma dubium and Moina micrura were found in the area to be usual by the second author ( $\mathrm{Gu}$, unpublished). Several tropical species, reported for ponds and paddy fields of Dali area (see Xiang et al., 2015); Ephemeroporus barroisi, Leberis diaphanus, Dunhevedia crassa King, 1853, were not found during our study neither. With these 
records, the number of taxa in Dali area could be increased until 40 species.

Lake Erhai region fauna during winter-spring is composed by three ecological groups of species. Most cladocera here ( 25 species), including all plankton taxa, are either Palearctic or widely distributed taxa. For some of them (Ceriodaphnia dubia, Ceriodaphnia reticulata, Daphnia galeata, Daphnia pulex, Pleuroxus aduncus, Oxyurellla tenuicaudis, Ilyocryptus cuneatus), Dali Area is on the southmost margin of distribution area. For these taxa, Dali Area is an "area of penetration" sensu Korovchinsky (2004, 2006), since their "areas of primary distribution" are in North Palearctic. Their appearance in Dali Area is probably a reflection of specific local conditions (moderately high altitude).

The second group are East Asian taxa (four species, Sida ortiva, Disparalona ikarus, Pseudochydorus bopingi and Alona kotovi) distributed from South-East Asia to Amur basin (Kotov, 2016). The third group are predominantly Paleotropical taxa (five species, Scapholeberis kingi, Macrothrix spinosa, Anthalona harti, Leydigia ciliata and Pleuroxus quasidenticulatus), they are rare in the area in spring-winter, only the latter species became frequent in spring. All these species have areas of primary distribution in the Oriental region and South China, but penetrate further north in lowland East China (see Korovchinsky, 2013).

In both sampling seasons, only parthenogenetic females were found in a majority of species. Few gamogenetic females and males were found in few common and abundant species: in winter for Coronatella rectangula, Chydorus spahaericus, Flavalona costata and Daphnia galeata, and in spring for Flavalona costata only. This shows that Dali area climate is mild enough to allow Palearctic species to overwinter as active populations, giving them an advantage over tropical species, which should overwinter at resting egg stage.

Many Cladocera described from Europe historically were presumed to be distributed across the whole Palearctic region. However, recent studies revealed that such taxa are often composed of sibling species, usually with limited ranges. For example, investigation of Chydorus sphaericus complex (Belyaeva \& Taylor, 2009; Klimovsky \& Kotov, 2015; Kotov et al., 2016) revealed that $C$. sphaericus s. str. is not present in the East Palearctic, being substituted there by $C$. cf. biovatus Frey, 1988, C. belyaevae Klimovsky \& Kotov, 2015 and several not yet described species of the clade. Genus Leptodora, presumed to be monotypical, is composed of at least two species distributed in West and East Palearctic (Korovchinsky, 2009); similar situation was revealed for genus Polyphemus (Xu et al., 2009). Pleuroxus trigonellus is substituted by sibling species in East Palearctic (Garibian et al., 2018). On the other hand, Daphnia curvirostris is distributed throughout the whole Palearctic region, but in East Asia it coexists with a cluster of local sibling-species (Kotov et al., 2006; Ishida et al., 2006).

Our data on two species of Aloninae, Flavalona costata and Coronatella rectangula, show that these populations are similar to European ones in both female and, more importantly, male morphology. In the family Chydoridae, differences in male morphology between sibling species are usually more pronounced than those in females (Frey, 1988b; Sinev, 1999, 2018; Neretina et al., 2018). Some sibling species can be morphologically distinguished by male morphology only (Klimovsky \& Kotov, 2015; Sinev \& Atroschenko, 2011; Sinev, 2013; Garibian et al., 2018). Our data suggests that $F$. costata and $C$. rectangula are monotypic within whole Palearctic region, and patterns of East-West distribution in Palearctic cladocera are rather variable even within one family.

All four species of the Cladocera recorded for continental China for the first time are substrate-associated. Two of these, Alona kotovi and Camptocercus uncinatus were previously recorded for Yunnan as $A$. quadrangularis and $C$. australis or $C$. rectirostris, respectively (Ji et al., 2015); these taxa are not present in South-East China. Our data confirms persistent problems with identifications of substrate-associated Cladocera in China (Xiang et al., 2015; Ji et al., 2015).

\section{ACKNOWLEDGEMENTS}

We are deeply grateful to Dr. Alexey A. Kotov for the valuable comments. The first author's visit 
and all sample collection were supported by National Science Foundation of China (NSFC) (No: 31670460) and Chinese National Programs for Fundamental Research and Development (973 Program, No. 2012CB956100). The morphological study of material was conducted solely by AYS under support from the Russian Science Foundation (grant 18-14-00325).

\section{REFERENCES}

ALONSO, M. 1996. Fauna Iberica. Crustacea Branchiopoda. Consejo Superior de Investigaciones Cientificas, Madrid, $486 \mathrm{pp}$.

BELYAEVA, M. \& D. J. TAYLOR. 2009. Cryptic species within the Chydorus sphaericus species complex (Crustacea: Cladocera) revealed by molecular markers and sexual stage morphology. Molecular Phylogenetics and Evolution, 50: 534-546.

BENZIE, J. A. H. 2005. The Genus Daphnia (Including Daphniopsis) (Anomopoda: Daphniidae). Guides to the Identification of the Microinvertebrates of the Continental Waters of the World. Vol. 21. Kenobi Productions, Ghent and Backhuys Publishers, Leiden.

CHATTERJEE, T., A. A. KOTOV, K. VAN DAMME, S. V. A. CHANDRASEKAR \& S. PADHYE. 2013. An annotated checklist of the Cladocera (Crustacea: Branchiopoda) from India. Zootaxa, 3667: 1-89. DOI: 10. 11646/zootaxa.3667.1.1

CHERTOPRUD, E. S., A. Y. SINEV \& I. DIMANTE-DEIMANTOVICA. 2017. Fauna of Cladocera and Copepoda from Xinjiang Uyghur Autonomous Region (China). Zoota$x a, 4258(6)$ : 561-573. DOI: 10.11646/zootaxa. 4258.6.5

CHIANG S. C. \& N. S. DU. 1979. Fauna Sinica: Crustacea: Freshwater Cladocera. Science Press: Beijing, 297 pp. [in Chinese]

DUMONT, H. J. \& J. PENSAERT. 1983. A revision of the Scapholeberinae (Crustacea: Cladocera). Hydrobiologia, 100: 3-45.

FREY, D. G. 1988a. Alona weinecki Studer on the subantarctic islands, not Alona rectangula Sars (Chydoridae, Cladocera). Limnology and Oceanography, 33: 1386-1411.

FREY, D. G. 1988b. Separation of Pleuroxus laevis Sars, 1861 from two species in North America: Pleuroxus straminius Birge, 1879 and Pleuroxus chiangi n. sp. (Cladocera, Chydoridae). Canadian Journal of Zoology, 66: 2534-2563.

FREY, D. G. 1991. The species of Pleuroxus and of three related genera (Anomopoda, Chydoridae) in southern Australia and New Zealand. Records of the Australian Museum, 43(3): 291-372.

GARIBIAN, P. G., A. N. NERETINA, A. A. KLIMOVSKY \& A. A. KOTOV. 2018. A new case of West-East differentiation of the freshwater fauna in Northern Eurasia: the Pleuroxus trigonellus species group (Crustacea: Cladocera: Chydoridae). Zootaxa, 4532 (4): 451-482. DOI: 10.11646/zootaxa.4532.4.1

HOLLWEDEL, W., A. A. KOTOV \& G. O. BRANDORFF. 2003. Cladocera (Crustacea: Branchiopoda) from the Pantanal (Brazil). Arthropoda Selecta, 12(2): 67-93.

HUANG X., X. SHI, A. A. KOTOV \& F. GU. 2014. Confirmation through genetic analysis of the existence of many local phyloclades of the genus Simocephalus (Crustacea, Cladocera) in China. PLoS ONE, 9(11): e112808. DOI: 10.1371/journal.pone.0112808

HUDEC, I. 2010. Fauna Slovenska III. Anomopoda, Ctenopoda, Haplopoda, Onychopoda (Crustacea: Branchiopoda). Veda, Bratislava, $496 \mathrm{pp}$.

IDRIS, B. A. G. 1983. Freshwater zooplankton of Malaysia (Crustacea: Cladocera). Perenbit University, Pertanian, Malaysia. 153 pp.

ISHIDA, S., A. A. KOTOV \& D. J. TAYLOR. 2006. A new divergent lineage of Daphnia (Cladocera: Anomopoda) and its morphological and genetical differentiation from Daphnia curvirostris Eylmann, 1887. Zoological Journal of the Linnean Society, 146: 385-405. JEONG, H. G., A. A. KOTOV \& W. LEE. 2012. A new species of the genus Ilyocryptus Sars, 1862 (Cladocera: Anomopoda: Ilyocryptidae) from the East Asian Palaearctic. Zootaxa, 3475: 36-44.

JEONG, H. G., A. A. KOTOV \& W. LEE. 2013. A new species of the genus Pleuroxus Baird (Cladocera: Anomopoda: Chydoridae) from Jeju Island, South Korea. Zootaxa, 3666: 31-40. 
JEONG, H. G., A. A. KOTOV \& W. LEE. 2014. Checklist of the freshwater Cladocera (Crustacea: Branchiopoda) of South Korea. Proceedings of the Biological Society of Washington, 127 (1): 216-228.

JEONG H. G., A. Y. SINEV, A. BRANCELJ, K. H. CHANG \& A. A. KOTOV. 2017. A new blind groundwater-dwelling genus of the Cladocera (Crustacea: Branchiopoda) from the Korean Peninsula. Zootaxa, 4341(4): 451-474. DOI: 10.11646/Zootaxa.4341.4.1

JI, G. H., X. F. XIANG, S. Z. CHEN, G. L. YU, A. A. KOTOV \& H. J. DUMONT. 2015. Annotated checklist of Chinese Cladocera (Crustacea: Branchiopoda). Part II. Order Anomopoda (families Macrotrichidae, Eurycercidae and Chydoridae). Zootaxa, 4044 (2): 241-269.

KLIMOVSKY, A. I. \& A. A. KOTOV. 2015. Cladocera (Crustacea, Branchiopoda) of Central Yakutia 3. Taxa from the Chydorus sphaericus s. 1. species group (Anomopoda, Chydoridae). Zoologicheskiy Zhurnal, 94: 1257-1267.

KOROVCHINSKY, N. M. 2004. Cladocerans of the order Ctenopoda of the world fauna (morphology, systematics, ecology, biogeography). KMK Press, Moscow, 410 pp. [In Russian]

KOROVCHINSKY, N. M. 2006. The Cladocera (Crustacea: Branchiopoda) as a relict group. Zoological Journal of the Linnean Society, 147: 109-124.

KOROVCHINSKY, N. M. 2009. The genus Leptodora Lilljeborg (Crustacea: Branchiopoda: Cladocera) is not monotypic: description of a new species from the Amur River basin (Far East of Russia). Zootaxa, 2120: 39-52.

KOROVCHINSKY， N. M. 2013. Cladocera (Crustacea: Branchiopoda) of South East Asia: history of exploration, taxon richness and notes on zoogeography. Journal of Limnology, 72 (s2), 109-124.

KOTOV, A. A. 2009. A revision of Leydigia Kurz, 1875 (Anomopoda, Cladocera, Branchiopoda), and subgeneric differentiation within the genus. Zootaxa, 2082: 1-68.

KOTOV, A. A. 2016. Faunistic Complexes of the Cladocera (Crustacea, Branchiopoda) of
Eastern Siberia and the Far East of Russia. Biology Bulletin, 43(9): 970-987. DOI: 10.1134/S1062359016090041

KOTOV, A. A. \& H. J. DUMONT. 2000. Analysis of the Ilyocryptus spinifer s. lat. species group (Anomopoda, Branchiopoda), with description of a new species. Hydrobiologia, 428: 85-113.

KOTOV, A. A., S. ISHIDA \& D. J. TAYLOR. 2006. A new species in the Daphnia curvirostris (Crustacea: Cladocera) complex from the eastern Palearctic with molecular phylogenetic evidence for the independent origin of neckteeth. Journal of Plankton Research, 28: 1067-1079.

KOTOV, A. A., H. J. JEONG \& W. LEE. 2012. Cladocera (Crustacea: Branchiopoda) of the south-east of the Korean Peninsula, with twenty new records for Korea. Zootaxa, 3368: 50-90.

KOTOV, A. A., N. M KOROVCHIMSKY, A. Y. SINEV \& N. N. SMIRNOV. 2011a. Cladocera (Crustacea, Branchiopoda) of the Zeya basin (Amurskaya Area, Russian Federation). 3. Systematic faunistic and zoogeographic analysis. Zoologichesky Zhurnal, 90: 402-411.

KOTOV, A. A., \& A. Y. SINEV. 2011. Cladocera (Crustacea, Branchiopoda) from the Zeya River basin (Amur Region, Russia) 2. Descriptions of new taxa. Zoologicheskiy Zhurnal, 90: 272-284.

KOTOV, A. A., N. M. KOROVCHINSKY, A. Y. SINEV, N. N. SMIRNOV, E. I. BEKKER \& N. G. SHEVELEVA. 2011b. Cladocera (Crustacea, Branchiopoda) from the Zeya River basin (Amur Region, Russia) 1. New taxa for the fauna of Russia. Zoologicheskiy Zhurnal, 90: 131-142.

KOTOV, A. A., A. Y. SINEV, P. G. GARIBIAN, A. N. NERETINA, H. J. JEONG, W. LEE, K.-S. CHAE \& G. S. MIN. 2017. Recent progress in studies of the Cladocera (Crustacea: Branchiopoda) of South Korea with seven new records for the Korean Peninsula. Journal of Species Research, 6 (Special Edition): 227-246. DOI: 10.12651/JSR.2017. 6(S).227

KOTOV, A. A. \& P. ŠTIFTER. 2006. Ilyocryptidae of the world. In: Dumont H.J. (ed.), 
Guides to the identification of the microivertebrates of the Continental Waters of the world, Vol. 22. Kenobi Productions, Ghent \& Backhuys Publishers, Leiden, $172 \mathrm{p}$.

KOTOV, A. A., K. VAN DAMME. \& M. ELIAS-GUTIERREZ. 2003. Differentiation between African Leydigia ciliata Gauthier, 1939 and Neotropical L. cf. striata Birabén, 1939 (Chydoridae, Anomopoda, Cladocera). Hydrobiologia, 505: 179-197.

KOTOV, A. A., D. P. KARABANOV, E. I. BEKKER, T. V. NERETINA \& D. J. TAYLOR. 2016. Phylogeography of the Chydorus sphaericus group (Cladocera: Chydoridae) in the Northern Palearctic. PLoS ONE, 11 (12), e0168711. DOI: 10.1371/ journal.pone. 0168711

LI, S., M. YU, G. LI, J. ZENG, Y. CHEN, B. GAO \& H. HUANG. 1963. A survey on Yunnan plateau lakes. Chinese Limnology and Oceanology, 5: 87-114.

LU, D. H. 1939. Cladocera from Erhai in winter. Transactions of the Zoological Institute of the National Peking Academy, 20, 1-16. [in Chinese]

LU, H., G. CHEN, Y. CAI, J. WANG, X. CHEN, L. DUAN \& H. ZHANG. 2016. Cladoceran community responses to eutrophication, fish introduction and macrophyte degradation over the past century in Lake Erhai. Journal of Lake Science, 28(1): 132-140. [In Chinese]

LIU G., Z. LIU, B. GU, J. M. SMOAK, Z. ZHANG. 2014. How important are trophic state, macrophyte and fish population effects on cladoceran community? A study in Lake Erhai. Hydrobiologia, 736: 189-204. DOI: 10.1007/s10750-014-1906-5

MA X., A. PETRUSEK, J. WOLINSKA, S. GIESSELER, Y. ZHONG, Z. YANG, W. HU, \& M. YIN. 2015. Diversity of the Daphnia longispina species complex in Chinese lakes: a DNA taxonomy approach. Journal of Plankton Research, 37(1): 55-65.

NERETINA, A. N., P. G. GARIBIAN, A. Y. SINEV \& A. A. KOTOV. 2018. Diversity of the subgenus Disparalona (Mixopleuroxus) Hudec, 2010 (Crustacea: Cladocera) in the New and Old World. Journal of Natural History, 52(3-4): 155-205. DOI: 10.1080/
00222933.2017.1411987

ORLOVA-BIENKOVSKAYA, M. Y. 2001. Daphniidae: genus Simocephalus. Guides to the identification of the microinvertebrates of the continental waters of the World 17. Backhuys, Leyden, $130 \mathrm{pp}$.

POPOVA E. V., A. PETRUSEK, V. KOŘINEK, J. MERGEAY, E. I. BEKKER, D. P. KARABANOV, Y. R. GALIMOV, T. V. NERETINA, D. J. TAYLOR \& A. A. KOTOV. 2016. Revision of the Old World Daphnia (Ctenodaphnia) similis group (Cladocera: Daphniidae). Zootaxa, 4161(1): 1-40. DOI: 10.11646/zootaxa.4161.1.1

SINEV, A. Y. 1999. Alona werestschagini sp. n., new species of genus Alona Baird, 1843, related to A. guttata Sars, 1862 (Anomopoda, Chydoridae). Arthropoda Selecta, 8(1): 23-30.

SINEV, A. Y. 2009. Cladocerans of the Alona affinis (Leydig, 1860) group from South Africa. Zootaxa, 1990: 41-54.

SINEV, A. Y. 2012. Alona kotovi sp. nov., a new species of Aloninae (Cladocera: Anomopoda: Chydoridae) from South Vietnam. Zootaxa, 3475: 45-54.

SINEV, A. Y. 2013. Cladocerans of Alona affinis group (Cladocera: Anomopoda: Chydoridae) from North America. Zootaxa, 3693(3): 329-343.

SINEV, A. Y. 2014. A comparative morphological analyses of four species of Camptocercus Baird, 1843 (Cladocera: Anomopoda: Chydoridae). Zootaxa, 3895 (2): 183-207. DOI: 10.11646/zootaxa.3895.2.3

SINEV, A. Y. 2015. Morphology and phylogenetic position of three species of genus Camptocercus Baird, 1843 (Cladocera: Anomopoda: Chydoridae). Zootaxa, 4040(2): 169-186. DOI: 10.11646/zootaxa.4040.2.4

SINEV, A. Y. 2016. Key for identification of Cladocera of the subfamily Aloninae (Anomopoda: Chydoridae) from South-East Asia. Zootaxa, 4200(4): 451-486. DOI: 10.11646/zootaxa.4200.4.1

SINEV, A. Y. 2018. Genus Camptocercus (Cladocera: Anomopoda: Chydoridae) in North America. Zootaxa, 4459 (3): 583-599. DOI: 10.11646/zootaxa.4459.3.11 
SINEV, A. Y. \& M. M. ATROSCHENKO. 2011. Revision of the genus Alonopsis Sars, 1862 and its position within Aloninae (Cladocera: Anomopoda: Chydoridae). Zootaxa, 2800: $1-17$.

SINEV, A. Y. \& H. G. DUMONT. 2016. Revision of the costata-group of Alona s. lato (Cladocera: Anomopoda: Chydoridae) confirms its generic status. European Journal of Taxonomy, 223: 1-38.

SINEV, A. Y., P. G. GARIBIAN \& Y. GU. 2016. A new species of Pseudochydorus Fryer, 1968 (Cladocera: Anomopoda: Chydoridae) from South-East Asia. Zootaxa, 4079 (1): 129-139. DOI: 10.11646/zootaxa.4079.1.9

SINEV, A. Y., Y. GU \& B. HAN. 2015. Cladocera of Hainan Island, China. Zootaxa, 4006 (3): 569-585. DOI: 10.11646/zootaxa.4006.3.9

SINEV, A. Y. \& N. M. KOROVCHINSKY. 2013. Cladocera (Crustacea: Branchiopoda) of Cat Tien National Park, South Vietnam. Journal of Limnology, 70 (s2): 125-141.

SINEV, A. Y. \& A. A. KOTOV. 2012. New and rare Aloninae (Cladocera: Anomopoda: Chydoridae) from Indochina. Zootaxa, 3334: 1-28.

SINEV, A. Y. \& L. SANOAMUANG. 2013. Notes on the cladoceran Pleuroxus (Picripleuroxus) quasidenticulatus (Smirnov, 1996) (Anomopoda: Chydoridae) from South-East Asia and Far East of Russia. Invertebrate Zoology, 10 (2): 269-280.

SINEV, A. Y. \& M. SILVA-BRIANO. 2012. Cladocerans of genus Alona Baird, 1843 (Cladocera: Anomopoda: Chydoridae) and related genera from Aguascalientes State, Mexico. Zootaxa, 3569: 1-24.

SINEV, A. Y. \& F. M. YUSOFF. 2015. Cladocera (Crustacea: Branchiopoda) of Sabah state in Borneo Island, Malaysia. Zootaxa, 4000 (5): 581-591. DOI: 10.11646/zootaxa.4000.5.7

SMIRNOV, N. N. 1992. The Macrothricidae of the world. Guides to the identification of the microivertebrates of the Continental Waters of the world, Vol. 1. SPB Academic Publishing, The Hague, 143 pp.

SMIRNOV, N. N. 1996. Cladocera: the Chydorinae and Sayciinae (Chydoridae) of the world.
Guides to the identification of the microivertebrates of the Continental Waters of the world, Vol. 11. SPB Academic Publishing, Amsterdam, $197 \mathrm{pp}$.

SMIRNOV N. N., A. A. KOTOV \& J. CORONEL. 2006. Partial revision of the aduncus-like species of Pleuroxus Baird, 1843 (Chydoridae, Cladocera) from the southern hemisphere with comments of subgeneric differentiation within the genus. Journal of Natural History, 40: 1617-1639.

VAN DAMME, K. \& H. J. DUMONT. 2008. Further division of Alona Baird, 1843: separation and position of Coronatella Dybowski \& Grochowski and Ovalona gen.n. (Crustacea: Cladocera). Zootaxa, 1960: 1-44.

VAN DAMME, K., A. Y. SINEV \& H. J. DUMONT. 2011. Separation of Anthalona gen.n. from Alona Baird, 1843 (Branchiopoda: Cladocera: Anomopoda): morphology and evolution of scraping stenothermic alonines. Zootaxa, 2875: 1-64.

WU, Q. \& Y. WANG. 1999. On the succession of aquatic communities in Erhai Lake. Journal of lake sciences, 11(3): 273-281.

XIANG, X. F., G. H. JI, S. Z. CHEN, G. L. YU, L. XU, B. P. HAN, A. A. KOTOV \& H. J. DUMONT. 2015. Annotated Checklist of Chinese Cladocera (Crustacea: Branchiopoda). Part I. Haplopoda, Ctenopoda, Onychopoda and Anomopoda (families Daphniidae, Moinidae, Bosminidae, Ilyocryptidae). Zootaxa, 3904 (1): 1-27. DOI: 10.11646/zootaxa.3904.1.1

XU, S., P. D. N. HEBERT, A. A. KOTOV \& M. E. CRITESKU. 2009. The non-cosmopolitanism paradigm of freshwater zooplankton: insights from the global phylogeography of the predatory cladoceran Polyphemus pediculus (Crustacea, Onychopoda). Molecular Ecology, 18: 5161-5179.

YANG, W., D. DENG, S. ZHANG, \& C. HU. 2014. Seasonal dynamics of crustacean zooplankton community structure in Erhai Lake, a plateau lake, with reference to phytoplankton and environmental factors. Chinese journal of oceanology and limnology, 32(5): 1074-1082. 